\title{
Folk Knowledge of an Individual Plant Specimen: The Case of the Royal Fern (Osmunda regalis L.) in Virestad Parish, Småland, Sweden
}

\author{
Ingvar Svanberg
}

Author Addresses: Uppsala Centre for Russian and Eurasian Studies, Uppsala University, Box 514, SE-751 20 Uppsala, Sweden ingvar.svanberg@ucrs.uu.se

Received: February 23, 2012

Volume 3: 63-67

Published: November 5, 2012

(C) 2012 Society of Ethnobiology

Abstract: Ethnobiological studies of local economic or folk religious uses of plants often rely on the assumption that plant use relates to folk knowledge about specific taxa. However, in some cases, folk knowledge is more about beliefs concerning an individual plant. When Carl Linnaeus traveled in 1749 through his native province of Småland, Sweden, he observed a striking specimen of a royal fern (Osmunda regalis L.), which was being used by a local healer. The appearance and unusually large size of this individual plant specimen were possibly responsible for its use. This species has not been used elsewhere in Sweden and historical data refer only to the single specimen observed by Linnaeus.

Key words: healer's knowledge, historical ethnobiology, intra-cultural diversity, Carl Linnaeus, folk knowledge.

\section{Introduction}

Today, as local ecological knowledge is rapidly disappearing and to a great extent has already been lost in most post-industrialized countries in Europe, historical data in archives are of particular interest to ethnobiologists (Heinrich et al. 2006; Luczaj 2008; Sõukand et al. 2010; Svanberg et al. 2011). However, the information the ethnobiologist acquires concerning various kinds of past local and traditional plant knowledge must be understood in its proper historical, ecological, and cultural context as much as is possible using historical records. Plant knowledge is not only a question of how a plant was used, but also when, where and by whom. These are simple, but crucial questions for ethnobiologists to ask and answer in order to understand the context of plant knowledge.

It is well documented that people in traditional societies all over the world had an intimate familiarity with local plants (Lévi-Strauss 1962). However, this knowledge varies within communities. Attention to intra-community and intra-cultural diversity of knowledge has increased among researchers (Pelto and Pelto 1975; Reyes-García et al. 2007; Newkirk et al. 2009). Clearly, knowledge about plants is not equally distributed within a particular community; certain skills are specific to men, women or children, others to certain categories such as healers, craftsmen or other specialists within a community. Knowledge may also vary according to economic and social context. Particular groups can comprise individuals who believe in the healing power of plants, as well as others who do not hold that belief. Attitudes can also change over time within a community or during an individual's lifetime (Anderson 2000; Pieroni 2003; Svanberg et al. 2011).

There are additional concerns that are important when considering plant knowledge surrounding the use of a specific taxon. When studying the cultural contexts between plants and people, many ethnobiologists focus on, and generalize about, a plant species or a folk taxon. Although scholars have increasingly moved away from cataloguing the use of various taxa, scientific or folk-defined species continue to be the focus of scholarly interest. It is important, however, for the ethnobiologist to be able to shift scale from species to populations to individuals, as plant knowledge can vary from knowledge about a species to intimate knowledge about a single plant.

\section{Materials and Methods}

In some cases, healers or other users can develop a relationship with a specific plant. Specific trees, for instance have been of great importance in traditional plant lore in Scandinavia. Various customs and medicinal practices have been connected with individual trees (Sydow 1935). Often, a strange appearance or an unusual growth is the reason why these particular trees were chosen for such purposes (Sydow 1973). The use of specific tree specimens for healing purposes was quite common in Scandinavian 
folk medicine (Sydow 1935; Brøndegaard 1978), a phenomenon that is also encountered elsewhere (e.g., Blackman 1925; Egenter 1981).

However, it is rare that individual healers develop a unique tie to a single small plant specimen. Such was the case with a single royal fern used by a local healer in Virestad parish in the Swedish province of Småland in the eighteenth and nineteenth centuries. It was discovered by Carl Linnaeus during his travels in Sweden in the 1740s and recorded in his notes. This relationship is analyzed here using narrative sources and source criticism, which relies on circumstantial evidence to take advantage of indications and clues available from a limited number of sources (Myrdal 2009).

During his travels in various Swedish provinces between 1732 and 1749, Linnaeus observed and noted interesting empirical data about folk biology, which are of relevance for ethnobiologists. The information Linnaeus gathered during his fieldwork was rendered in his Flora lapponica (1737) and Flora svecica (1755), both published in Latin and therefore extensively read by an international audience. These published data about local Swedish and Sámi folk biology give very little contextual information, but they have become widely distributed in the scientific community. The origin of much of this information has been obscured, and the information about folk knowledge is usually stripped from botanical handbooks. However, thanks to the travelogues Linnaeus published and his preserved hand-written travel diaries, some contextual information about when, where, and from whom he gathered his data about the use of certain plants exists. His travelogues, rather than the floras he published, are important sources for ethnobiological research.

\section{Results: Linnaeus and Folk Biological Knowledge}

With Linnaeus' notes as the exception there are no available records about local knowledge of the royal fern (Osmunda vulgaris L.) in Sweden. When Linnaeus traveled through his native province of Småland on the road to the southernmost province Skåne, in May 1749, he made the following annotation when he passed Virestad parish:

'Safsa-buske [= Royal fern bush] was a renowned plant in Virestad parish, which was only to be found in one place, that is to say a small islet in Fanhult's creek. The wise woman, known as Ingeborg in Mjärhult, used, when she lived in Mjärhult, to visit this bush during the mornings in silence, and fasting, to consult with, I know not whom. This is why the inhabitants of Virestad call the bush for Ingeborg $i$ Märbult's predikstol 'the pulpit of Ingeborg of Mjärhult’ (Linnaeus 1751).

The fern specimen was (for Swedish examples of the species) an imposing example of Osmunda vulgaris $\mathrm{L}$. Linnaeus writes that it was about 1.2 meters high and 3.6 meters in diameter (Linnaeus 1751). Not surprisingly it was looked on more as a shrub ('buske') than a fern.

Linnaeus had had already written about the healer Mother Ingeborg just after her death during his visit in 1741 (Linnaeus 1745). She was famous all over the country as a seeress and as a folk-healer, and she was a well-known local healer in this part of Småland. Little biographical data are available, but apparently she learned to use plants in remedies from her mother, and she gathered various plants and grasses during Midsummer Eve for that purpose. At seventy years of age, Ingeborg was put on trial in 1740 for acting as a healer.

According to records made by Linnaeus himself, Mother Ingeborg could describe her patients' illness simply by handling their clothes. She thought that every person had a double that followed them like a reversed reflection in calm water or as an antipode in a downwards position. If the double should injure an underground spirit, the person fell ill. The illness was cured by pouring milk or something similar into a northbound stream, on a tree or in a churchyard. Unfortunately no further information about her use of plants or healing methods is available.

The plant name safsabuske was recorded for the first time by Linnaeus in Virestad 1749. The etymology of the name remains obscure. Although the royal fern is the largest fern species in Sweden, which grew along small rivers and brooks with oligotrophic water, no other local names have been recorded. The species occurred - and still occurs - here and there in the southernmost part of Sweden north to mid-Småland. With its striking appearance, this impressive fern species must have attracted the interest of the peasantry. However, if such was the case, it is surprising that oral folk records in archives and published sources have nothing to say about the plant.

\section{Discussion}

Ferns have played an important role in Scandinavian and European folk botany. The many folk-views about them held across large parts of Eurasia have been discussed by Gunda (1989). However, information about the Osmunda vulgaris from Småland is a very local tradition tied specifically to the specimen observed by 
Linnaeus. Only this particular plant specimen was used by the local healers. Nothing is known about the species' role in the folk botany of other parts of Sweden or in Denmark. However, John Gerard in his herbal 1597 and Nicholas Culpepper in his herbal 1653 recommended its rhizomes for medical use (Grieve 1931). It has also been mentioned in recent Southern European and British folk medicine (Vickery 1995; Molina et al. 2009). In Scotland its rhizome has been reported for use as a love charm (Darwin 1996).

The Swedish local name safsabuske was probably also not used for the taxon as such, but for the particular specimen in Virestad parish. However, Linnaeus regarded it as a provincial plant name and used it as such in his Flora svecica (1755). It thereby became the Swedish name of the species, and, shortened to safsa in 1848, is still the one used in Swedish handbooks.

Linnaeus' descriptions of the fasting and silent woman in Mjärhult who used the royal fern as an oracle plant gives us interesting insights into eighteenth century traditional folk knowledge and magical methods of diagnosis. Much later, the Swedish author and scholar in traditional folk-lore, Eva Wigström, recorded local traditions about the same royal fern specimen. According to her, there were stories about a witch that once lived in Virestad parish who gained power over Satan himself. Satan gave her the fern to plant and knowledge on how to use it correctly in order to have universal knowledge (Wigström 1896).

The tradition of the huge royal fern specimen in Virestad survived until the nineteenth century, and its magical usefulness seems to have benefited several generations of healers. Ethnologist Gunnar Olof Hyltén-Cavallius in the 1860 s wrote about the same plant specimen: 'Still in our own time, the so-called Kloke Herren ('Wise Gentleman') in Fanhult likewise used branches of the royal fern bush as a potent drug against bewitching and illness'. In this case, over hundred years after Linnaeus' visit it was another healer, this time a male, who used the plant (HylténCavallius 1863-64). For him it was used for the derivation of medicine.

The royal fern is a rare species that lives along rivers with oxygen-rich water. It grows in gravely places in or near water. The habitat of this particular specimen was destroyed when water levels decreased in the 1880s (Schiöler 1931). Although the royal fern as a species was distributed over southern Sweden, the records from Virestad stand out as unique in Swedish folk biological tradition. Its use was connected with that particular plant, not with the taxon as such. One reason for this must have been that the Virestad specimen was large and outstanding in many ways. Scholars have long emphasized the significance of 'the unusual' in popular belief and folk perceptions of other organisms (Sydow 1973; Kolosova 2010). The other reason is that local wise persons discovered the plant and developed a kind of mythical tradition around it. Therefore, the biocultural domain that materialized in this relationship must be regarded as unique, not necessary based on folk wisdom on the species as such.

\section{Conclusions}

Ethnobiologists study the folk biology and the biocultural domains that develop in human and plant and animal interactions (Svanberg et al. 2011). However, historically, the primary aim has not been to theorize and generalize about folk biological knowledge but to exploit it for other purposes. This is also true of Linnaeus, who, in a more programmatic way than anyone before him, exhorted scholars to direct a searchlight on traditional folk knowledge about nature. He stressed the importance of not neglecting, but carefully investigating 'peasant botany', as he called it (Linnaeus 1745).

For Linnaeus and his contemporaries, folk knowledge of plants and animals was a storehouse of information that scholars could draw upon. The purpose of this was to benefit the national economy, that is, to find biological resources that could be of advantage for the nation. Linnaeus and other researchers around him, in this fashion, headed towards economic botany and applied botany, which reminds us of contemporary bioprospecting (Stearn 1994).

Although the royal fern has been utilized as a medicinal plant elsewhere in Europe, the "use" in Småland did not derive from a long-lasting experience of the species' usefulness as such. It was rather its striking appearance and unusually large size of the individual specimen at Virestad that attracted and therefore gave rise to its magical reputation, which the healers perpetuated. Linnaeus through his observations and notes preserved the knowledge of a very local folk tradition. Even though the locals shared the view of the particular plant specimen as magical and useful, the species as such was never of interest in Swedish folk botany.

\section{Acknowledgements}

I would like to thank Professor Eugene N. Anderson, Professor Andrea Pieroni, Professor Lukasz Łuczaj, Steve Wolverton and the anonymous referees for their helpful comments on earlier drafts of this paper. 


\section{References Cited}

Anderson, M. 2000. Sami Children and Traditional Knowledge. In Ecological Knowledge in the North: Studies in Ethnobiology, edited by I. Svanberg and H. Tunón, pp. 55-66. Swedish Science Press, Uppsala.

Blackman, W. S. 1925. Sacred Trees in Modern Egypt. The Journal of Egyptian Archaeology 11:56-57.

Brøndegaard, V. J. 1978. Folk og flora: dansk etnobotanik 1. Rosenkilde og Bagger, Copenhagen.

Darwin, T. 1996. The Scots Herbal: The Plant Lore of Scotland. Mercat Press, Edinburgh.

Egenter, N. 1981. The Sacred Trees around Goshonai/Japan. Asian Folklore Studies 40:191-212.

Grieve, M. 1931. A Modern Herbal: The Medicinal, Culinary, Cosmetic and Economic Properties, Cultivation and Folk-Lore of Herbs, Grasses, Fungi, Shrubs \& Trees with all their Modern Scientific Uses 2. Harcourt, Brace \& Company, New York.

Gunda, B. 1989. A virágzó páfrány. In A rostaforgató asszony, edited by B. Gunda, pp. 71-84. Múzsák Kiadó, Budapest.

Heinrich, M., J. Kufer, M. Leonti and M. Pardo-deSantayana. 2006. Ethnobotany and Ethnopharmacology: Interdisciplinary Links with the Historical Sciences. Joumal of ethnopharmacology 107:157160. DOI: $10.1016 /$ j.jep.2006.05.035.

Hyltén-Cavallius, G. O. 1863-64. Wärend och Wirdarne 1. F. A. Norstedt \& Söner, Stockholm.

Kolosova, V. B. 2005. Name-Text-Ritual: The Role of Plant Characteristics in Slavic Folk Medicine. Folklorica: Journal of the Slavic and East European Folklore Association 10: 44-62.

Lévi-Strauss, C. 1962. La pensée sawvage. Plon, Paris. Linnaeus C. 1745. Öländska och Gothländska Resa, på Riksens Högloflige Ständers befallning förrättad Ahr 1741. Gottfried Kieselwetter, Stockholm.

Linnaeus C. 1751. Skånska Resa, På Höga Öfwerhetens Befallning Förrättad Ar 1749. Lars Salvius, Stockholm.

Łuczaj, Ł. 2008. Archival Data on Wild Food Plants used in Poland in 1948. Journal of ethnobiology and ethnobotany 4:4. DOI: 10.1186/1746-4269-4-4.

Molina M., V. Reyes-García and M. Pardo-deSantayana. 2009. Local Knowledge and Management of the Royal Fern (Osmunda regalis L.) in Northern Spain: Implications for Biodiversity Conservation. American
Fern Journal 99: 45-55. DOI: 10.1640/0002-844499.1.45.

Myrdal, J. 2009. Source Pluralism and a Package of Methods: Medieval Tending of Livestock as an Example. In Methods and the Medievalist: Current Approaches in Medieval Studies, edited by M. Lamberg, J. Keskiaho, E. Räsänen and O. Timofeeva, pp. 134-154. Cambridge Scholars, Newcastle upon Tyne.

Newkirk, C. N., K. S. Oths, W. W. Dressler, and J. E. Dos Santos. 2009. Intracultural Diversity in Food Knowledge in Southern Brazil. Ecology of Food and Nutrition 48:285-302. DOI: 10.1080/03670240903022304

Pelto, P. J. and G. H. Pelto. 1975. Intra-Cultural Diversity: Some Theoretical Issues. American ethnologist 2:1-18. DOI:10.1525/ae.1975.2.1.02a00010.

Pieroni, A. 2003. Wild Food Plants and Arbëresh Women in Lucania, Southern Italy. In Women and Plants: Gender Relations in Biodiversity Management Concervation, edited by P.L. Howard, pp. 66-82. Zed Books, London.

Reyes-García, V., N. Martí, T. McDade, S. Tanner and V. Vadez. 2007. Concepts and methods in studies measuring individual ethnobotanical knowledge. Journal of Ethnobiology 27: 182-203. DOI: 10.2993/02780771(2007)27[182:CAMISM]2.0.CO;2.

Schiöler, S. 1931. Safsan: en vallfart till mor Ingeborg i Mjärhult predikstol. Sveriges natur 22: 41-50.

Sõukand R., R. Kalle and I. Svanberg. 2010. Uninvited Guests: Traditional Insect Repellents in Estonia used against the Clothes Moth Tineola bisselliella, Human Flea Pulex irritans and Bedbug Cimex lectularius. Journal of Insect Science 10: 150. DOI: 10.1673/031.010.14110.

Stearn, W. T. 1994. Linnaeus as an Economic Botanist. Botanical Journal of Scotland 46:702-706.

Svanberg, I., Ł. Łuczaj, M. Pardo-de-Santayana and A. Pieroni. 2011. History and Current Trends of Ethnobiological Research in Europe. In Ethnobiology, edited by E. N. Anderson, D. Pearsall, E. Hunn and N. Turner, pp. 191-212. Wiley-Blackwell, Hoboken, NJ.

Sydow, C. W. 1935. Något om träden i folkets tro och sed. In Svenska kulturbilder XI-XII, pp. 227-258.

Skoglund, Stockholm.

Sydow, C. W. 1973. Det ovanligas betydelse i tro och sed. In Folkdikt och folk:tro, edited by A. B. Rooth, pp. 200-214. Gleerups, Lund. 
Vickery, R. 1995. A Dictionary of Plant Lore. Oxford University Press, Oxford.

Wigström, E. 1896. Växtlifvet i folkets tro och diktning. Ord och Bild 5:12-19.

\section{Biosketch}

Ingvar Svanberg is a senior lecturer in ethnobiology, living and working in Sweden. His current research focuses on companion animals in various ethnographic contexts, historical aquaculture, and ethnobiological information in eighteenth century traveller reports from Russia and Siberia. 